\title{
Biochemical and Microbial Properties of Palm Wine: Effect of Tapping Length and Varietal Differences
}

\author{
Detto Karamoko1, N’Dédé Théodore Deni' ${ }^{2}$ Jean-Luc Aboya Moroh1, \\ Koffi Maïzan Jean-Paul Bouatenin², Koffi Marcellin Dje ${ }^{2}$ \\ ${ }^{1}$ Laboratory of Food Microbiology and Biotechnology, Department of Biochemistry and Food Sciences, \\ University Peleforo Gon Coulibaly of Korhogo, Korhogo, Cote d'Ivoire \\ ${ }^{2}$ Laboratory of Biotechnology and Food Microbiology, Department of Food Sciences and Technology, \\ University Nangui Abrogoua of Abidjan, Abidjan, Cote d'Ivoire \\ Email: romaric1976@yahoo.fr, tdjeni@yahoo.fr, moroh_aboya@yahoo.fr, \\ bouat08@gmail.com,djekoffr@yahoo.fr
}

Received 5 January 2016; accepted 22 July 2016; published 25 July 2016

Copyright (C) 2016 by authors and Scientific Research Publishing Inc.

This work is licensed under the Creative Commons Attribution International License (CC BY). http://creativecommons.org/licenses/by/4.0/

(c) () Op Open Access

\begin{abstract}
The effects of variety and tapping length on several physical, biochemical, nutritional and microbiological parameters (viscosity, pH, Total Titratable Acidity (TTA), fermenting microorganisms, contaminants) of palm wine extracted from two varieties of palm oil tree (Dura and Tenera) were studied. Each variety presented its own palm wine specific characteristics regarding the chosen parameters. Microbiological and biochemical contents of palm wine were determined during the tapping of Dura and Tenera felled oil palm trees for 4 weeks. Some differences in chemical compositions between fresh palm wine samples of two palm trees varieties were observed. The exudates obtained during the first day of tapping of Dura palm wine were very sugary, less sour and did not contain substantial concentrations of alcohol but the highest loads of microorganisms were observed in Tenera palm wine. Throughout the tapping of palm wine, yeasts and lactic acid bacteria population changed with undoubtedly influence on the palm wine quality.
\end{abstract}

\section{Keywords}

Viscosity, Palm Wine, Fermentation, Palm Oil Trees

\section{Introduction}

Palm wine is made from the fermented sap of tropical plants of the palmae family, such as the oil palm (Elaeis

How to cite this paper: Karamoko, D., Deni, N.T., Moroh, J.-L.A., Bouatenin, K.M.J.-P. and Dje, K.M. (2016) Biochemical and Microbial Properties of Palm Wine: Effect of Tapping Length and Varietal Differences. Food and Nutrition Sciences, 7, 763771. http://dx.doi.org/10.4236/fns.2016.79077 
guineensis), coconut palm (Cocus nucifera), date palm (Phoenix dactylifera), nipa palm (Nypa fruticans), kithul palm (Caryota urens), ron palm (Borassus aethiopum) and raffia palm (Raphia hookeri) [1] [2]. The unfermented sap is clear, sweet, colourless syrup containing about $10 \%-12 \%(\mathrm{w} / \mathrm{v})$ sugar, which is mainly sucrose [3]. Upon fermentation by the natural microflora, the level of this sugar decreases as it is converted to alcohol and other products whereas the sap becomes milky white due to the increased microbial suspension resulting from the prolific growth of fermenting organisms [4]. It becomes a whitish, effervescent, alcoholic beverage consumed in very large quantities in West Africa, and known throughout the major parts of Africa under various names, such as "mimbo" in Cameroon, "nsafufuo" in Ghana, an "emu" in Nigeria and "bandji" in Côte d'Ivoire [5] [6]. It is widely consumed in tropical regions where palms grow such as Asia, South America, Africa and more particularly in Côte d'Ivoire amongst all socioeconomic groups. In such areas, the beverage plays an important role in the culture of the people and most African countries have their own palm wine, including Côte d'Ivoire [6] [7]. It has been associated to life farmer, because being less expensive and produced in the farming surroundings [8]. Indeed the consumed volumes are in the same way order of size than those of modern beers. Because of the nutritional wealth of this non fermented sap, it is often proposed to infants whose mother cannot produce the necessary milk for the nursing [9] [10].

However, like many other traditional fermented foods in Africa, the production of palm wine is by the age-old method of chance inoculation and uncontrolled fermentation. Therefore, the usual variations in the quality and stability of the product are not unexpected. The sap of the palm tree is tapped and allowed to undergo spontaneous fermentation, which promotes the proliferation of yeast species for the conversion of the sweet substrate into an alcoholic beverage containing important nutritional components, including amino acids, proteins, vitamins and sugars [11]. The process of tapping palm wine involves first felling or cutting down the tree, leaving the felled tree for a period of about 2 weeks for the sap to concentrate, followed by tapping for up to 8 weeks. Many problems associated with the different aspects of indigenous food fermentation processes including lack of good manufacturing procedure or hygiene code; lack of knowledge of nutritional and toxicological implication of the fermentation are important with particular reference to palm wine tapping and processing in that the quality is determined among others by the effectiveness of the tapping or fermentation process. Important works have been done in West Africa, especially in Ghana and Nigeria during the last 20 years on various aspects of palm wine including its production and composition [12] [13], but to our knowledge, variations in palm wine quality throughout tapping and oil palm tree varietal effect have not yet assessed particularly. In Côte d'Ivoire, palm wine is mainly obtained from palm oil tree Elaeis guineensis which involves many varieties. As palm wine has a significant role in customary practices in Africa, it is important that the microbiology and biochemistry of its tapping process are well understood. Thus, this study was carried out to investigate the microbiological and biochemical changes which occur in palm wine during the tapping of two varieties of felled oil palm trees.

\section{Materials and Methods}

\subsection{Materials and Sampling}

Palm wine samples were obtained during the tapping of 20 palm trees (E. guineensis) of two varieties (Dura and Tenera) at the University Nangui Abrogoua (Côte d'Ivoire) over a period of 5 months. Collection of palm wine during tapping was normally done twice a day by the tapper, but in this study samples were collected at three day intervals each morning of sampling day at 7:00 AM in stomacher bags from the beginning until the end of tapping. These samples were immediately transported to the laboratory for analyses, carried out in replicates.

\subsection{Biochemical Analysis}

\subsubsection{Determination of $\mathrm{pH}$ and Total Titratable Acidity}

The $\mathrm{pH}$ of palm wine samples was determined directly using a pH-meter (pH-meter P 107, CONSORT, Bioblock, France) after calibration with standard buffers. Total titratable acidity was determined by titrating samples against $0.1 \mathrm{M} \mathrm{NaOH}$ using $1 \%$ phenolphthalein as indicator as described by [14] and expressed as percentage of lactic acid.

\subsubsection{Determination of Total and Reducing Sugars}

Total sugars in palm wine samples were determined using phenol sulphuric acid method according to Dubois [6] 
[15], while reducing sugars were quantified as previously described by Bernfeld [16]. Two independent measurements were made on each sample and results were expressed in $\mathrm{g} / \mathrm{L}$.

\subsubsection{Ethanol Content}

Ethanol content was determined by gas chromatographic analyses, carried out using a Shimadzu CG-14A gas chromatograph. Filtered samples $(2 \mathrm{~mL})$ were directly injected into the system. The temperature was set at $8^{\circ} \mathrm{C}$ $\mathrm{min}^{-1}$. Injector and detector temperature were $200^{\circ} \mathrm{C}$ and $250^{\circ} \mathrm{C}$, respectively. Helium at $2 \mathrm{~kg} \cdot \mathrm{cm}^{-2}$ was used as a carrier gas and the external standard method was used for the quantitative determination of ethanol.

\subsubsection{Viscosity}

The Thermo Scientific HAAKE Falling Ball Viscometer type C was used to measure the viscosity of palm wine. It provides a very accurate way of measuring the viscosity of transparent Newtonian liquids and gases and meets the requirements of the German DIN 53015 as well as ISO 12058 standards. The time for rolling and sliding movements of a ball through the sample in an inclined cylindrical measuring tube is measured at $30^{\circ} \mathrm{C}$. The sample viscosity is correlated with the time needed by a ball to traverse a definite distance. By turning the measuring tube upside down again the return of the ball may also be used for an additional measurement. The test results were given as dynamic viscosity in the internationally standardized, absolute units of centi Poise (cP).

\subsection{Enumeration of Microorganisms}

The palm wine samples were shaken by hand in the stomacher bag and tenfold serial dilutions were prepared and spread-plated for determination of micro-organism counts. After dilutions, enumeration of total aerobic mesophile was carried out using plates of Plate Count Agar (PCA, Difco 0479-17-3; Difco Laboratories, Detroit, MI, USA) which were incubated at $30^{\circ} \mathrm{C}$ for 2 days. Lactic acid bacteria (gram positive catalase negative rods, cocci and coccoids) were enumerated by pour plate on DeMan, Rogosa and Sharpe Agar (MRS, Merck 10660; Merck KGaA, Darmstadt, Germany) containing 10 mg/mL cycloheximide (ICN 100183 Biomedical Inc., Aurora, OH, USA) to suppress yeast growth after incubation at $30^{\circ} \mathrm{C}$ for 3 days in an anaerobic jar with anaerocult A (Merck). Yeasts and moulds were enumerated on plates of Sabouraud Chloramphenicol agar (BIO-RAD, France) which were incubated at $30^{\circ} \mathrm{C}$ for $3-5$ days. Enumeration of total and faecal coliforms was carried out using plates of Violet Red Bile Lactose agar (VRBL, Merck 10660, Merck, Darmstadt, Germany) which were incubated for $24 \mathrm{~h}$ at $30^{\circ} \mathrm{C}$ for total coliforms and $44^{\circ} \mathrm{C}$ for faecal coliforms. Enterococci species were enumerated on plates of Bile Esculin Azide agar (AES Laboratoire, COMBOURG France) after incubation at $37^{\circ} \mathrm{C}$ for 2 days.

\subsection{Statistical Analysis}

The data obtained were subjected to analysis of variance (Statistica, 99 Edition, Alabama, USA) and mean differences determined by Duncan's multiple range tests. Significance of variations in the analyzed data was tested at $95 \%$ confidence limit.

\section{Results and Discussion}

Table 1 shows values of biochemical parameters obtained in palm wine every day during tapping of two varieties of oil palm trees (Dura and Tenera). Most of the values decrease during tapping of oil palm tree. The initial $\mathrm{pH}$, reducing sugars and ethanol contents were respectively $5.23 \pm 0.18,45.55 \pm 4 \mathrm{~g} / \mathrm{L}$ and $0.08 \% \pm 0.02 \%$ in Dura variety. These values are not similar to the mean values usually reported by other authors. Throughout the tapping, a subsequent drop of $\mathrm{pH}$ and sugars content associated with an increase of the titratable acidity and alcohol rate were observed. During the collecting process, it is highly susceptible to spontaneous yeast-lactic fermentation of the sugary sap. This process is reported to be rapid under sunlight. Sources of fermenting microorganisms are tapping implements (knife and bamboo tube) and air. The weak rate of sugars observed in Tenera variety would be had to either to the important chemical changes in the sap herself or either to high loads of microorganisms in a container which converted the fermentable sugars into alcohol. Ours results were similar with results obtained by [14] [17]. The initial viscosity content in Dura palm wine was very high (8.28 cP) in the earlier days of tapping contrarily to Tenera palm wine which viscosity was about four time less (2.61cP) (Table 1). However the values obtained for both varieties were higher than those of [18] who found $1 \mathrm{cP}$ for palm wine of 
Table 1. Biochemical parameters obtained in palm in every day during tapping of two varieties of palm oil trees.



TS: Total sugar; RS: Reducing sugar; TTA: total titratable acidity.

1 day. During tapping, a very high decrease was observed in Dura palm wine viscosity the first 13 days, corresponding to a period of active fermentation to rejoin palm wine of Tenera after which no significant variation was observed until the end of tapping (Figure 1). The results do not correspond with those obtained by Osuwa [18] indicating that the decrease in viscosity occurs during the three (3) first days. The decrease in palm wine viscosity was also reported by Osuwa [18] but also for other fermented beverages such as Boza [19].

The chemical composition of fresh palm wines collected at every three sampling day intervals during tapping is showed in Figure 2 and Figure 3. The sap obtained from Dura variety during the first day of tapping were very sugary, less sour and did not contain substantial concentrations of alcohol. The initial total soluble sugars content of fresh palm wine was $501.68 \pm 26 \mathrm{~g} / \mathrm{L}$ and do not correlate with the observed values of Odunfa [20] and Olasupo [21] who reported fresh palm wine sugar content of $10 \%$ - 12\%. Significant differences observed in sugar contents regarding varieties of palms but also due to microbial populations found in palm wines.

The process of tapping of palm wine from felled trees can be considered as semi-continuous fermentation. Periodically (everyday, twice a day), samples were collected and added to the previous samples in a container placed near the tree. In the traditional setting, palm wine tapping instruments, especially receiving vessels are used repeatedly without cleaning the inner surfaces to remove the microbial deposits. So, rapid deterioration of sugary taste is observed shortly after the fresh exudate is obtained. This is the result of fermentation of endogenous sugars by the natural flora of the fermenting sap which is whitish in appearance and also exhibit vigorous effervescence. The results are similar to those obtained by Amoa [14]. The higher increase of ethanol (Figure 3(c)) was observed in Dura oil palm tree. This ethanol increased from $0.08 \%$ to 3.18\%. This was very revealing as it showed that the development of alcohol in palm wine was more pronounced during the tapping. The concentration of alcohol in palm wine samples collected during the tapping were found to be low and dependent on several factors including the nature/system of fermentation. Samples collected in first day of tapping did not contain more than alcohol. Palm wine tappers collect their wine in the morning and evening, but wine collected in the morning would have accumulated throughout the night. In general, lactic acid bacteria produce very little ethanol (parts per million levels), and they use pyruvate as the principal final hydrogen receptor. On the other hand, yeast produces ethanol as a major end product [22]. The $\mathrm{pH}$ and total acidity of all palm sap samples were significantly different among the samples $(P<0.05)$. The $\mathrm{pH}$ values of all palm sap samples varied from 5.23 to 3.43 while total acidity found in a range from $0.17 \%$ to $0.88 \%$, as calculated based on organic acid presented in palm sap [6] [23]. Microorganisms, mainly lactic acid bacteria produced organic acids (manly 


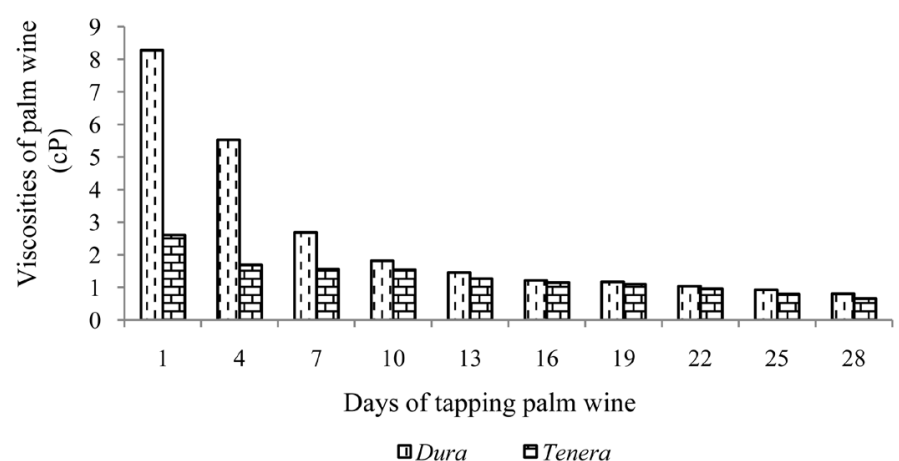

Figure 1. Changes in viscosities content during the tapping of different palm wine samples.

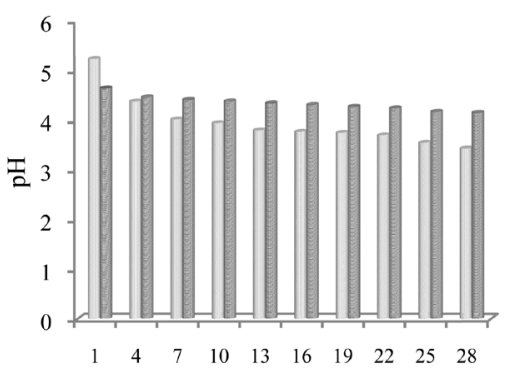

Days of tapping palm wine

1 Dura =Tenera

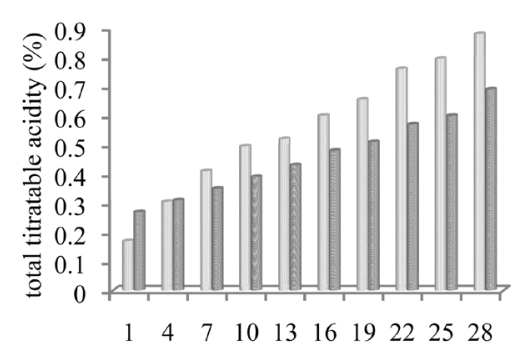

Days of tapping palm wine

: Dura בTenera

Figure 2. Changes in $\mathrm{pH}$ and total titratable acidity content during the tapping of different palm wine samples.



Days of tapping palm wine 1 Dura I Tenera

(a)

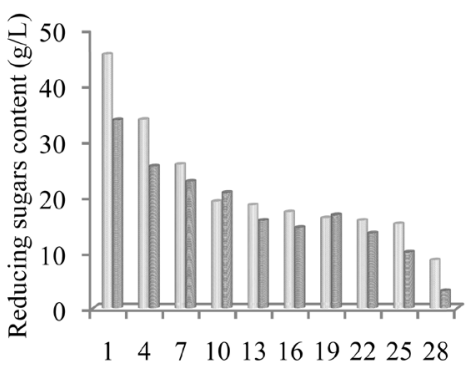

Days of tapping palm wine

1. Dura ᄃ Tenera

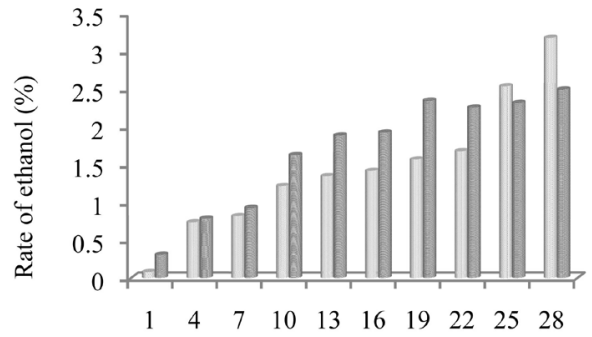

Days of tapping palm wine

$\therefore$ Dura $\quad$ Tenera

(c)

Figure 3. Changes in the rate of ethanol, total and reducing sugars content during the tapping of different palm wine samples. 
lactic acid), which then increase in total acidity and decrease in $\mathrm{pH}$ value. Normally, natural palm sap showed neutral pH approximately 7 as reported by Jiybunjerdkul [24] and Lasekan [25]. Hence, a high percentage of total acidity and low $\mathrm{pH}$ indicates the initial fermentation step of palm sap, for example, during collecting time. In addition the results of $\mathrm{pH}$, total titratable acid and organic acids confirmed the importance of lactic acid bacteria in the tapping of palm wine. In fact, lactic acid bacteria were considered to be responsible for the rapid acidification of the product as the acetic acid bacteria were not isolated in the palm wine samples on the first days of tapping. The results are similar to those obtained by Amoa-Awua [14]. The decrease in sugar content is a clear indication that a large portion of the sugars is fermented especially during the tapping in Dura oil palm tree. Moreover, the sugar level decreases rapidly as it is converted to alcohol and other products and the observed increase in acidity is indicative of the fact that production of acids in the tapping of sap occurred concurrently with alcohol production. Similar observations were reported by Obire [4] and Olasupo [21].

The sap of the palm tree has been shown to be a rich medium capable of supporting the growth of various types of micro-organisms, as high numbers of aerobic mesophiles, lactic acid bacteria, yeasts, Enterococci, coliforms and sulphite reducing bacteria were found in palm wine during tapping. In discussing the population of the various microorganisms in palm wine, the following factor appears important. That to prevent insect and larvae infestation and also facilitate the oozing of the sap, the tapper cuts thin slices off the walls of the receptacle daily to expose a fresh layer. This physically removed the microbiota that had colonized the walls of the receptacle, thus reducing the microbial load in the chamber. In spite of all measures, the microorganism colonizes the palm wine. This could be explained by the results presented in Figure 4, which showed that these micro-organisms in fresh palm wine might have originated from those that colonize those parts of the palm stalk of the male inflorescence, the leaf petiole, the felt (afabric-like outgrowth of the frond petiole used to cover the tapping hole), the cross strips and xylem stream which are covered with fluffy hairy outgrowths. Our results are similar to those obtained by Faparusi [26]. Some of them were also brought by the tapper, tapping materials and insects attracted by the sap sugar (Figure 5). Our results showed high loads of microorganisms already the first day in palm wines of both varieties (Dura and Tenera). Microbiological examination of Tenera palm wine samples recorded aerobic mesophilic counts of $10.2 \pm 0.1 \mathrm{log} \mathrm{cfu} / \mathrm{mL}$. Yeast counts was $5.6 \pm 0.3 \mathrm{log} \mathrm{cfu} / \mathrm{mL}$, lactic



(a)

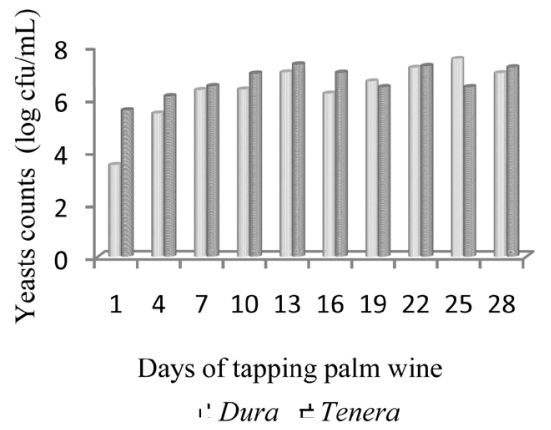

(c)

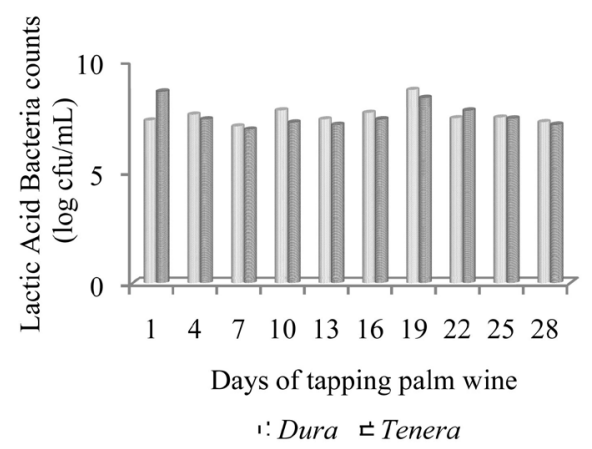

(b)



(d)

Figure 4. Mean values of the population of various microorganisms in different samples of palm wine during the tapping. (a) Aerobic mesophiles; (b) Lactic acid bacteria; (c) Yeasts; (d) Enterococcus sp. 


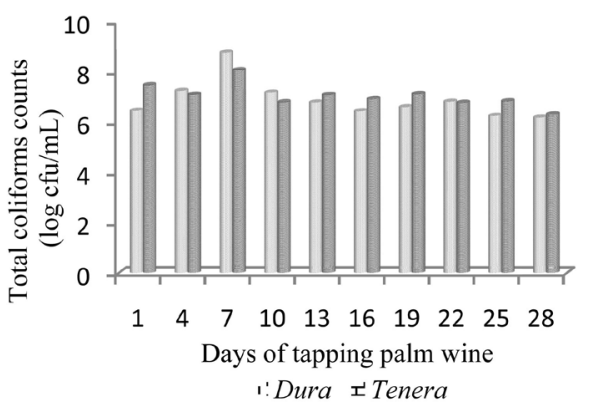

(a)

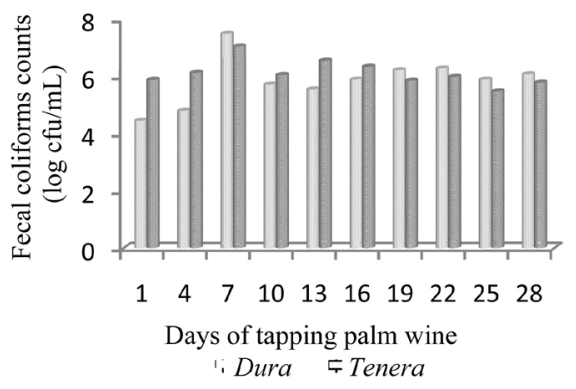

(b)

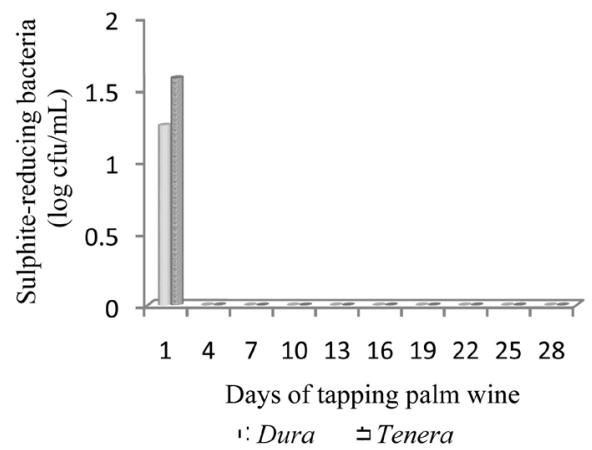

(c)

Figure 5. Mean values of the population of various micro-organisms in different samples of palm wine during the tapping. (a) total; (b) Faecal coliforms; (c) Sulpfite reducing bacteria.

acid bacteria counts was $8.6 \pm 0.2 \log \mathrm{cfu} / \mathrm{mL}$, Enterococci species counts $7.5 \pm 0.2 \log \mathrm{cfu} / \mathrm{mL}$. Total coliforms and fecal coliforms counts from palm wines were $7.5 \pm 0.2 \log \mathrm{cfu} / \mathrm{mL}$ and $5.9 \pm 0.2 \log \mathrm{cfu} / \mathrm{mL}$ respectively. Throughout tapping of Dura palm wine, a drastic increase was observed in yeast loads from average values of $3.5 \pm 0.3$ to $7.5 \pm 0.2 \mathrm{log} \mathrm{cfu} / \mathrm{mL}$ after 25 day (Figure 4(c)). It is possible that differences in the chemical composition of palm wine tapped from Dura and Tenera oil palm trees favour the evolution of yeast biota. During the first week of competition between microorganisms in successive fermentations was unfavorable of Enterococci, coliforms (total and fecal) and sulphite reducing bacteria. The second week was characterized by a decrease in the profit of coliforms and Enterococci training decrease in $\mathrm{pH}$ and an increase of ethanol in palm wines. The decrease of $\mathrm{pH}$ and increase of ethanol allow acidification palm wine provided by the population of lactic acid bacteria founded in the palm wine samples, which was very little during the semi-continuous fermentations. Indeed, microorganisms such as lactic acid bacteria produce organic acids including lactic allowing increased titratable acidity and therefore lower $\mathrm{pH}$. Normally, the sap of the palm has an approximately neutral $\mathrm{pH}$ according to the work done by Jitbunjerdkul [24] with Lindsay [22]. Therefore, high titratable acidity and the low $\mathrm{pH}$ of palm wine obtained indicate that initial fermentation of the sap was done before collection. As the results of $\mathrm{pH}$, titratable acidity and lactic acid confirm the presence of lactic acid bacteria in palm wine. Similar observations were reported by Amoa-Awua [14], who confirm that the lactic acid bacteria were considered to be responsible for the rapid acidification of the product as the acetic acid bacteria were not isolated in the palm wine samples on the first day of tapping. The sugars content dropped indicates that some sugar was fermented during the tapping of Dura palm wine. In addition, the rapid decrease in content of sugars could be explained by a change in alcohol and other products. The increase in acidity indicates production of acid in palm wine as had previously indicated work done by Olasupo [21] and those of Obire [4]. Yeasts little affected by acidification were the cause of the increase of ethanol content in palm wine. In fact, loads yeast gradually increase during tapping palm trees. The differences in the chemical composition of palm wine product in Dura and Tenera could favor the evolution of load yeasts. In addition, the increase of yeasts population could be related to the nutritional quality of palm wine [27]. The increase in yeast population of palm wine trained the increase of ethanol rates observed in Dura palm wine during tapping. Samples collected in 28th day of tapping contained more ethanol. This high rate of ethanol could be due by yeast but also by lactic acid bacteria. According to [22], lactic acid 
bacteria also produce low ethanol content and use pyruvate as the principal final hydrogen receptor.

A substantial part of coliforms and sulphite reducing bacteria were present in the different saps with the highest loads in those collected in tenera palm wine when compared with corresponding values for dura palm wine (Figure 5). The presence of coliforms obtained in the palm wines could be explained itself by a human or animal fecal contamination on the place of tapping and also by the presence of bugs attracted by sugars contained in palm wines. Our results agree with those of Tchiendji [28]. In addition the occurrence of coliforms and sulphite reducing bacteria are indication of poor hygienic handling of the palm wine sampled. These microorganisms are contaminants from contaminated containers or from untreated water that is normally used in the dilution of palm wine [3].

\section{Conclusion}

Palm wine is a beverage obtained from the fermentation of palm saps from palm tree (Elaeis guineensis) by indigenous microbes. To conclude in this study, important microbial changes occurred in the various palm wine samples during tapping. The highest loads of microorganisms were observed in tenera palm wine at first day. Those undoubtedly have an effect on the biochemical and the safety of this beverage, and so far its nutritional value. The disappearance of all sulphite reducing counts was observed after 4 days of tapping palm wines. However, the presence of coliforms obtained from this study is associated with the unhygienic handling of the beverage, as these bacterial isolates are known to have negative effects on the consumers' health. The presence of an important population of lactic acid bacteria could have a benefic effect on consumer health and thus increasing the interest of this beverage. Therefore, further studies on their technological properties could help to elucidate the involvement of these micro-organisms in the food safety and the improvement of the consumer digestion; as palm wine is consumed with its wild micro-organisms generally without any toxicity has been observed.

\section{References}

[1] Dayo-Owoyemi, I., Boboye, B. and Akinyosoye, F.A. (2008) Organoleptic Analysis of Doughs Fermented with Yeasts from a Nigerian Palm Wine (Elaeis guineensis) and Certain Commercial Yeasts. The Open Microbiology Journal, 2, 115-120. http://dx.doi.org/10.2174/1874285800802010115

[2] Sambou, B., Goudiaby, A., Daouda, D., Ervik, F. and Camara, M.C. (2002) Palm Wine Harvesting by the Bassari Threatens Borassus aethiopum Populations in North-Western Guinea. Biodiversity and Conservation, 11, 1149-1161. http://dx.doi.org/10.1023/A:1016005025090

[3] Ogbulie, T.E., Ogbulie, J.N. and Njoku, H.O. (2007) Comparative Study on the Shelf Life Stability of Palm Wine from Elaeis guineensis and Raphia hookeri Obtained from Okigwe, Nigeria. African Journal of Biotechnology, 6, 914-922.

[4] Obire, O. (2005) Activity of Yeast Species in Palm Sap Obtained from Three Areas in Edo State, Nigeria. Journal of Applied Science Environmental Management, 9, 25-30.

[5] Ezeronye, O.U. and Okerentugba, P.O. (2000) Genetic and Physiological Variants of Yeasts Selected from Palm Wine. Mycopathologia, 152, 85-89. http://dx.doi.org/10.1023/A:1012323721012

[6] Karamoko, D., Djeni, N.T., N'Guessan, K.F., Bouatenin, K.M.J.-P. and Dje, K.M. (2012) The Biochemical and Microbiological Quality of Palm Wine Samples Produced at Different Periods during Tapping and Changes Which Occured during Their Storage. Food Control, 26, 504-511. http://dx.doi.org/10.1016/j.foodcont.2012.02.018

[7] Ukhun, M.E., Okolie, N.P. and Oyerinde, A.O. (2005) Some Mineral Profile of Fresh and Bottled Palm Wine, a Comparative Study. African Journal of Biotechnology, 4, 829-832.

[8] Uzogara, S.G., Ezeokoli, N.F. and Uzogara, E.O. (1987) Tyramine Content of Some Nigerian Foods. Ecology of Food and Nutrition, 19, 257-264. http://dx.doi.org/10.1080/03670244.1987.9990969

[9] Ayernor, G.K.S. and Mathews, J.S. (1971) The Sap of the Palm Elaeis guineensis Jacq as Raw Material for Alcoholic Fermentation in Ghana. Tropical Science, 13, 71-83.

[10] Ezeagu, I.E. and Fafunso, M.A. (2003) Biochemical Constituents of Palm Wine. Ecology and Food Nutrition, 42, 213222. http://dx.doi.org/10.1080/03670240390226222

[11] Okafor, N. (1972) Palm Wine Yeasts from Parts of Nigeria. Journal of the Science of Food and Agriculture, 23, 13991407. http://dx.doi.org/10.1002/jsfa.2740231203

[12] Uzochukwu, S.V.A., Balogh, E., Tucknot, O.G., Lewis, M.J. and Ngoddy, P.O. (1994) Volatiles Constituents of Palm Wine and Palm Sap. Journal of the Science of Food and Agriculture, 94, 405-411. http://dx.doi.org/10.1002/jsfa.2740640403 
[13] Van Pee, W. and Swings, J.G. (1971) Chemical and Microbiological Studies on Congolese Palm Wines (Elaeis guineensis). East Africa Agriculture and Forest Journal, 36, 311-314.

[14] Amoa-Awua, W.K., Sampson, E. and Tano-Debrah, K. (2007) Growth of Yeasts, Lactic and Acetic Bacteria in Palm Wine during Tapping and Fermentation from Felled Oil Palm (Elaeis guineensis) in Ghana. Journal of Applied Microbiology, 102, 599-606. http://dx.doi.org/10.1111/j.1365-2672.2006.03074.x

[15] Dubois, M., Gilles, K., Hamilton, J.K., Rebers, P.A. and Smith, F. (1956) Colometric Method for Determinations of Sugars and Related Substances. Analytic Chemistry, 280, 350-356. http://dx.doi.org/10.1021/ac60111a017

[16] Bernfeld, D. (1955) Amylases, Alpha and Beta. In: Colowick, S.P. and Kaplan, N.O., Eds., Methods in Enzymology, Academic Press Inc., New York, 149-154.

[17] Borse, B.B., Rao, J.L., Ramalakshmi, K. and Raghavan, B. (2007) Chemical Composition of Volatiles from Coconut Sap (Neera) and Effect of Processing. Food Chemistry, 101, 877-880. http://dx.doi.org/10.1016/j.foodchem.2006.02.026

[18] Osuwa, J.C. and Mbamara, S.U. (2008) Viscosities of Palm Oil and Palm Wine as Quality Indicators. Journal of Food Technology, 6, 170-172.

[19] Gotcheva, V., Pandiella, S.S., Angelov, A., Roshkova, Z. and Webb, C. (2001) Monitoring the Fermentation of the Traditional Bulgarian Beverage Boza. International Journal of Food Science and Technology, 36, 129-134. http://dx.doi.org/10.1046/j.1365-2621.2001.00429.x

[20] Odunfa, S.A. and Oyewole, O.B. (1997) African Fermented Foods. In: Wood, B.J.B., Ed., Microbiology of Fermented Foods, Springer, Boston, 713-752.

[21] Olasupo, N.A. and Obayori, O.S. (2003) Utilization of Palm Wine (Elaeis guineensis) for the Improved Production of Nigerian Indigenous Alcoholic Drink-Ogogoro. Journal of Food Processing and Preservation, 27, 365-372. http://dx.doi.org/10.1111/j.1745-4549.2003.tb00523.x

[22] Lindsay, R.C. (1996) Flavors. In: Fennema, O.R., Ed., Food Chemistry, Marcel Dekker Inc., New York, 723-765.

[23] Phaichamnan, M., Posri, W. and Meenune, M. (2010) Quality Profile of Palm Sugar Concentrate Produced in Songkhla Province, Thailand. International Food Research Journal, 17, 425-432.

[24] Jitbunjerdkul, S. (1989) Effect of Antimicrobial Agents on the Quality of Palm Sugar Products. Songklanakarin Journal of Science and Technology, 11, 161-165.

[25] Lasekan, O., Buettner, A. and Christlbaure, M. (2007) Investigation of Important Odorant of Palm Wine (Elaeis guineensis). Food Chemistry, 105, 15-23. http://dx.doi.org/10.1016/j.foodchem.2006.12.052

[26] Faparusi, S.I. (1973) Origin of Initial Microflora of Palm Wine from Oil Palm Trees (Elaeis guineensis). Journal of Applied Bacteriology, 36, 559-565. http://dx.doi.org/10.1111/j.1365-2672.1973.tb04142.x

[27] Nwachukwu, I.N., Ibekwe, V.I., Nwabueze, R.N. and Anyanwu, B.N. (2006) Characterisation of Palm Wine Yeast Isolates for Industrial Utilization. African Journal of Biotechnology, 5, 1725-1728.

[28] Tchiendji, C. (1985) Le vin de palme d’Elaeis guineensis.Ecole Supérieure Agronomique et des industries alimentaires. Université de Nancy, Nancy.

\section{Submit or recommend next manuscript to SCIRP and we will provide best service for you:}

Accepting pre-submission inquiries through Email, Facebook, Linkedin, Twitter, etc

A wide selection of journals (inclusive of 9 subjects, more than 200 journals)

Providing a 24-hour high-quality service

User-friendly online submission system

Fair and swift peer-review system

Efficient typesetting and proofreading procedure

Display of the result of downloads and visits, as well as the number of cited articles

Maximum dissemination of your research work

Submit your manuscript at: http://papersubmission.scirp.org/ 